Discussion Paper No. 09-086

\title{
Enterprise Systems and Innovations
}

Benjamin Engelstätter

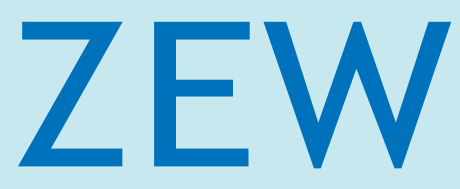

Zentrum für Europäische Wirtschaftsforschung $\mathrm{GmbH}$

Centre for European

Economic Research 
Discussion Paper No. 09-086

\title{
Enterprise Systems and Innovations
}

\author{
Benjamin Engelstätter
}

Download this ZEW Discussion Paper from our ftp server:

ftp://ftp.zew.de/pub/zew-docs/dp/dp09086.pdf

Die Discussion Papers dienen einer möglichst schnellen Verbreitung von neueren Forschungsarbeiten des ZEW. Die Beiträge liegen in alleiniger Verantwortung der Autoren und stellen nicht notwendigerweise die Meinung des ZEW dar.

Discussion Papers are intended to make results of ZEW research promptly available to other economists in order to encourage discussion and suggestions for revisions. The authors are solely responsible for the contents which do not necessarily represent the opinion of the ZEW. 


\section{Non-technical summary}

Enterprise systems, i. e. company-wide packages of enterprise software for planning, calculating and managing business processes, are widely used in various industry branches throughout many countries. In general employed to replace firms' usually poorly connected legacy software, enterprise systems might yield improvements in operational integration affecting the entire organization. On the one hand, Enterprise Resource Planning (ERP) and Supply Chain Management (SCM) systems may provide information for process innovations by reducing idle times, saving data mining or identify bottlenecks and shortages. Customer Relationship Management (CRM) systems, on the other hand, yield a database to identify customer preferences which might be a useful source for product innovations.

This paper studies the relationship between enterprise systems and firms' innovational performance. The analysis is based on a knowledge production function and employs a two step estimation procedure which takes into account the bias due to potential self selection during the firms' decision to innovate. The basis of the analysis builds a German enterprise data set, containing enterprises of different industry branches from the manufacturing and service sector.

The results are twofold. On the one hand, adoption of ERP and SCM systems increases the propensity to realize process innovations. In addition, ERP system usage positively affects the number of realized process innovations. These impacts are not only short-term based, in fact they remain stable during two to four years. On the other hand, only CRM influences firms' product innovational performance as it increases the propensity to acquire product innovations, although this positive effect is only short-term based. 


\section{Das Wichtigste in Kürze}

Unternehmensweite Softwarepakete zur Planung, Kalkulation und Steuerung betrieblicher Prozesse sind nahezu weltweit in verschiedensten Wirtschaftszweigen verbreitet. Im Allgemeinen wird diese sogenannte Unternehmenssoftware dazu verwendet, die üblicherweise schlecht vernetzten älteren Softwaresysteme des Unternehmens zu ersetzen. Dabei könnte sie zu Verbesserungen in der Verflechtung operativer Prozesse führen, die sich auf das gesamte Unternehmen auswirken. Beispielsweise könnten Enterprise Resource Planning (ERP)- und Supply Chain Management (SCM)-Systeme durch reduzierte Leerlaufzeiten und die Identifikation von Engpässen Informationen für Prozessinnovationen liefern. Customer Relationship Management (CRM)Systeme dagegen bieten eine Datenbasis, die Auskunft über Präferenzen und Neigungen der Kunden gibt und eine nützliche Quelle für Produktinnovationen sein könnte.

Diese Studie untersucht den Zusammenhang zwischen Unternehmenssoftware und der Innovationstätigkeit der Unternehmen. Die Analyse basiert dabei auf einer Wissensproduktionsfunktion und verwendet eine zweistufige Schätzmethode, welche die Verzerrung durch mögliche Selbstselektion der Unternehmen bei der Entscheidung, Innovationen einzuführen, berücksichtigt. Die Grundlage der Analyse bildet ein Unternehmensdatensatz, der deutsche Unternehmen verschiedener Branchen des verarbeitenden Gewerbes und des Dienstleistungssektors umfasst.

Die empirischen Untersuchungen zeigen zweierlei Ergebnisse. Zum einen steigert die Einführung von ERP- und SCM-Systemen die Neigung der Unternehmen, Prozessinnovationen einzuführen. Zusätzlich beeinflusst der Einsatz eines ERP-Systems die Anzahl der eingeführten Prozessinnovationen positiv. Diese Wirkungen sind dabei nicht nur kurzfristiger Natur, sondern bleiben auf lange Sicht von zwei bis vier Jahren stabil. Auf der anderen Seite beeinflusst nur ein CRM-System die Leistungsfähigkeit der Unternehmen hinsichtlich der Produktinnovationen, indem 
dessen Nutzung die Neigung der Unternehmen hin zur Einführung von Produktinnovationen erhöht. Dieses Ergebnis ist allerdings von kurzfristiger Natur und verliert seine Gültigkeit, wenn man einen Zeitraum von zwei Jahren und mehr betrachtet. 


\title{
Enterprise Systems and Innovations ${ }^{\S}$
}

\author{
Benjamin Engelstätter*
}

\begin{abstract}
This paper analyzes the relationship between the three main enterprise systems (Enterprise Resource Planning (ERP), Supply Chain Management (SCM), Customer Relationship Management $(\mathrm{CRM}))$ and firms' innovational performance. It studies whether the enterprise systems have impacts on process as well as product innovations. Using German firm-level data, the results show that ERP and SCM systems foster the firms' likelihood to generate process innovations. In addition, ERP systems also show a positive impact on process innovation intensity. These results do not only emerge for the short-run of two years or less but remain also stable in the long-run of two to four years. Concerning product innovational performance only, CRM systems increase the firms' likelihood to acquire product innovations, although the impact only emerges for the short-run and vanishes if the long-run perspective is taken into account.
\end{abstract}

Keywords: Innovation, Product Innovation, Process Innovation, Enterprise Systems, Selectivity, Enterprise Resource Planning, Supply Chain Management, Customer Relationship Management JEL Classification: L10, M20, O31

\footnotetext{
$\S$ I would like to thank Irene Bertschek, Daniel Cerquera, Francois Laisney and Pierre Mohnen for helpful comments and suggestions. All errors are my own.

* ZEW, ICT Research Group, P.O. Box 103443, D-68304 Mannheim, email: engelstaetter@zew.de
} 


\section{Introduction}

Covering a large range of software products supporting day-to-day business operations and decision-making, company-wide suites of business software, namely enterprise systems in short, are devoted to particular process integration across the value chain. The three main enterprise systems, Enterprise Resource Planning (ERP), Supply Chain Management (SCM) and Customer Relationship Management (CRM), are widespread throughout many industries in numerous areas around the world. The purpose of these systems is to automate operations from supply management, inventory control, manufacturing scheduling, sales force automation and almost any other dataoriented management processes. SAP, the largest global enterprise software vendor, estimates the complete market for core enterprise applications including ERP, SCM and CRM in 2008 at nearly \$39 billion [31].

In general, enterprise systems ought to replace the firms' legacy software systems, which are usually poorly connected and spread out all over the firm. In addition, improvements in operational integration realized through enterprise system adoption can affect the entire organization. Therefore, ERP and SCM systems might positively foster innovational activity as they reduce idle times and save data mining or identify bottlenecks and shortages, thus providing information for process enhancements. With the firm-wide database updated in real time, which both systems provide, the effects of process innovations can be directly pictured, compared and controlled. CRM systems, on the other hand, yield a database of customer preferences, which can be a useful source for product innovations.

Although the usage of information and communication technology (ICT) applications in general is suspected to enhance firms' innovational performance [22], the potential impact of enterprise systems on innovational performance in particular is still not investigated. The literature in this field is scarce, offering only a few studies which examine the benefits of enterprise systems for 
innovational activity. Empirical evidence on the basis of firm-level data covering this topic is still lacking at present. Therefore, this study aims to provide the first empirical evidence of the impact of adopting any of the three main enterprise systems on firms' innovational performance. In order to achieve useful results, the present study relies on a unique database consisting of German firms from the manufacturing industry and from service sectors.

Using a two step approach the results provide first evidence of innovational activity fostered through enterprise system usage. The adoption of ERP and SCM systems increases the propensity to realize process innovations. In addition, ERP system usage has a positive impact on the amount of acquired process innovations. These impacts are not only short-term based, in fact they stay also stable in the long-run of two to four years. The usage of CRM systems, on the other hand, does not have an impact on process innovations but positively impacts the propensity to realize product innovations, although this impact only holds on a short-term basis of two years or less.

The paper proceeds as follows: Section 2 gives an overview of the appropriate literature covering the benefits of enterprise systems in general and their potential effects on innovational performance in particular. Section 3 pictures the estimation approach whereas section 4 presents the dataset. Section 5 contains the estimation results. Concluding remarks are given in section 6 .

\section{Methodological and theoretical Framework}

\subsection{Benefits of Enterprise Systems in general}

Replacing complex interfaces between different systems with standardized cross-functional transaction automation, ERP systems use a source of data that integrates enterprise functions such as sales and distribution, materials management, production planning, financial accounting, cost control and human resource management [1]. An ERP system is expected to reduce order cycle 
times, which in return might lead to improved throughput, customer response times and delivery speeds $[8,25]$. Due to automated financial transactions, cash-to-cash cycle times and the time needed to reconcile financial data at the end of a quarter or year can be minimized [23, 24]. The ERP system collects all enterprise data once during the initial transaction, stores the data centrally and performs updates in real time. The standardized firm-wide transactions and centrally stored enterprise data will also greatly facilitate the governance of the firm [26, 32].

IT-based SCM systems coordinate and integrate the complete flow of information, materials and finances and improve operational as well as business planning [10]. The real-time planning capabilities of SCM systems enable firms to react quickly to supply and demand changes [18], serving customers in a timely and comprehensive manner [4]. By reducing inventory levels, holding costs, spoilage and lead times, SCM systems can directly improve inventory management and increase profitability through a reduction of costs, avoiding lost sales and improving customer satisfaction [4]. Lower coordination, sales, general and administrative costs, improved decisionmaking and forecasting are additional benefits generated through SCM system usage [10]. Based on its ability of information sharing, collaborative planning and forecasting replenishment, a SCM system will also lead to improvements in decisions on order quantity, lowered time and costs of order processing or increased order frequencies combined with reduced lead time.

Providing the appropriate infrastructure, e. g. enabling effective sales force automation, centralized customer data warehousing and data mining paired with decision support and reporting tools, CRM systems facilitate the development of long-term relationships with customers [21, 34]. A CRM system is also expected to lead to superior customer loyalty, reduced cost of sales and services or improved bottom-line profits [5]. It reduces duplication in data entry and maintenance by providing a centralized firm-wide database of customer information, capturing all their needs and wants. In addition, this database replaces systems maintained by individual sales people, institutionalizes 
customer relationships and prevents the loss of organizational customer knowledge, when sales staff leaves the firm [18]. The database might also reduce costs via streamlining repetitive transactions and sales processes [7].

\subsection{Effects of Enterprise Systems on Firms’ innovational Performance}

Enterprise systems might affect the firms' innovational performance through different channels. First of all, enterprise systems foster further innovations directly based on the benefits they provide. The firm-wide database generated and updated by the ERP system, for example, provides every employee with necessary data in real-time, thus making data-mining obsolete and enabling the workers to be more innovative and flexible [9]. ERP systems are also expected to provide strategic benefits and build additional business innovations, for example by enabling new market strategies or building up new process chains [33]. Using a SCM system all departments receive in time information about the resources necessary, therefore bottlenecks and idle time should be reduced to a minimum. Both systems together generate a suitable and more flexible [10, 25] working environment and, with product lifecycles and resource usage shown in real-time, room for process improvements and innovations should be easy to identify. In addition, with the firm wide database updated in real time, the results of the innovations can be directly pictured, controlled and compared, providing even more room for improvements. A CRM system, on the other hand, might be particularly useful for successful product innovations as its data offers a complete picture of the customers' wants and needs. In general, this knowledge of customers' preferences is expected to shape the firms' innovation success [20]. Therefore, firms with CRM systems in use should experience significant advantages in product enhancement and design as they can stick to a rich database of customer information and adjust their production accordingly.

Besides direct effects, enterprise systems might also indirectly increase innovational performance as the systems may foster the introduction of some organizational enhancements which have been 
proven to facilitate the generation of more innovations. [36] proclaims that business units are more innovative once they reach a more centralized network position that enables them to access new knowledge generated by other units faster. Enterprise systems fit perfectly into this context as in particular ERP enhances the intern network capabilities of the firms by providing a centralized database with access for every employee and business unit and fastening connections between them. As the communication between the units is accelerated with an ERP system in use, the innovational activity of the firm might, according to [36], also increase. [6] show that firms generate more innovations with established upstream, respectively downstream, contacts to suppliers and customers. [29] support this argument as they emphasize the great value of backwards and horizontal knowledge linkages for process innovations. With their focus on communication with suppliers and customers, SCM and CRM systems are expected to maintain current and generate new upstream and downstream contacts far easier, generating more knowledge linkages in the process. Consequently, firms with SCM and CRM systems in use have access to a large pool of knowledge, which will, according to [6] and [29], be helpful to create more innovations.

\section{Research methodology}

\subsection{Knowledge Production Function}

The present study will be based on an innovation respectively knowledge production function as introduced by [14]. The basic assumption is that the output of the innovation process represents a result of several inputs linked to research and ongoing knowledge accumulation, such as, e. g., capital, investment or human capital [13]. [30] augment this function with even more inputs like enterprise characteristics, firm resources and organizational capabilities to take the different routes through which knowledge might influence the firms' innovation activities into account. In addition, I include enterprise systems in the knowledge production function, providing first insights of the 
relationship between enterprise system adoption and the firm's innovational activity. To summarize, the probability that a firm will generate either product or process innovations is given by

$$
y_{\mathrm{i}}^{*}=X_{\mathrm{i}}^{\prime} \beta_{1}+I D_{\mathrm{i}}{ }^{\prime} \beta_{2}+E S_{\mathrm{i}}^{\prime} \beta_{3}+\varepsilon_{\mathrm{i}} \quad y_{\mathrm{i}}=1 \text { if } y_{\mathrm{i}}^{*} \geq 0 ; y_{\mathrm{i}}=0 \text { otherwise, }
$$

where $y_{\mathrm{i}}$ stands for the $i$ th firm's product or process innovation respectively. $X_{\mathrm{i}}$ covers firm characteristics expected to impact innovations activity, e. g., size, capital, ICT capital, human capital and East German heritage. $I D_{\mathrm{i}}$ includes the control dummies for industry sectors and $E S_{\mathrm{i}}$ contains the enterprise systems used by firm $i$.

\subsection{Innovation Intensity}

As the selection equation (1) shows to which extent enterprise system usage foster the firms' innovation propensity, the next consecutive step will be to reveal the impacts of enterprise systems on innovation intensity, measured, e. g., by the number of innovations realized in the firm. The innovational intensity can be specified as

$$
z_{\mathrm{i}}^{*}=Z_{\mathrm{i}}{ }^{\prime} \lambda_{1}+I D_{\mathrm{i}}{ }^{\prime} \lambda_{2}+E S_{\mathrm{i}}{ }^{\prime} \lambda_{3}+\gamma_{\mathrm{i}} \quad z_{\mathrm{i}}=z_{\mathrm{i}}{ }^{*} \text { if } y_{\mathrm{i}}=1 ; z_{\mathrm{i}}=0 \text { if } y_{\mathrm{i}}=0
$$

where $z_{\mathrm{i}}^{*}$ is the unobserved latent variable accounting for the $i$ th firm's process respectively product innovation intensity. $Z_{\mathrm{i}}$ is a set of determinants expected to affect innovation intensity and contains, in general, the same variables as in equation (1). As above, $E S_{\mathrm{i}}$ pictures enterprise system usage of firm $i$ and $I D_{\mathrm{i}}$ contains the industry control dummies.

\subsection{Estimation Procedure}

Estimating equations (1) and (2) via maximum likelihood, count data methods have to be used for inference as the innovation intensity is measured by the number of realized innovations in this 
study. Taking the possible selection into account, I consider both the hurdle and the zero-inflated model which allow for a separate treatment of zeros, i. e. non-innovators, and strictly positive outcomes [38]. Comparing both model types, the zero-inflated model differs from the hurdle-model in that, with $p_{\mathrm{i}}=P\left(y_{\mathrm{i}}=1\right), z_{\mathrm{i}}=z_{\mathrm{i}}^{*}$ for the full range of $z_{\mathrm{i}}{ }^{*}$ and not just for strictly positive values. The appropriate model for the present dataset will be chosen in section 5 based on usual model selection criteria. Both models can either be based on the Poisson or the negative binomial distribution. Allowing for overdispersion, frequently occurring in applied economics, the negative binomial distribution seems to be the more reasonable choice in the present analysis. In the following, the appropriate distribution will be selected based on a likelihood-ratio test ${ }^{1}$.

\section{The Data}

The dataset used in this study results from two computer-aided telephone surveys conducted in 2004 and 2007 by the Centre for European Economic Research (ZEW). These surveys laid a specific focus on the diffusion and use of ICT in German companies. In general, the interviewee was the chief executive officer of the firms who could also decide to pass questions on to a corresponding employee like, e. g., the head of the ICT department. Each wave of this ICT-dataset originally contains information of about 4,000 firms with five or more employees, representatively chosen from important service and manufacturing sectors in Germany. The data basis for the sample stems from the credit rating agency Creditreform. This agency provides the largest data base on firms available in Germany. Creditreform collects some basic information like address, sector and firm size on all enterprise that ever applied for a bank credit. The selection from the population of German firms was stratified according to industries (seven branches of the manufacturing

\footnotetext{
${ }^{1}$ Both proposed models assume at least conditional independence between the selection process (1) and the count process (2). I acknowledge that this simplification can be relaxed by using the endogenous selection model proposed by [35]. However, the endogenous selection model, although theoretically identified by its functional form [27], should rely on exclusion restrictions to produce credible outcomes. As the current dataset does not provide a suitable exclusion restriction, I pass inference based on the endogenous selection model on to further research with new data and stick to the zero-inflated and hurdle models to establish a baseline.
} 
industry and seven selected service sectors), to three size classes and to two regions (East/West Germany) and. There have been asked as many firms as needed until all strata were filled.

Besides detailed information on the usage of several other ICT applications, the dataset provides the usage level of the three main enterprise software applications ERP, SCM and CRM. The possible level of usage in the questionnaire was none, minor or complete. For this study, I built a dummy variable for the use of each software application which takes the value one if a firm uses the software at least to a minor degree or completely and zero otherwise ${ }^{2}$. In addition, the surveys contain information about the firms' workforce, total investments and other variables, like e. g. organizational practices.

The 2007 survey covers the product and process innovations in the time of 2004 to 2006 . However, the answers on enterprise system usage in this survey are related to the year 2007. Since the survey is organized as a panel dataset, I use the software usage reported in 2004 to construct the needed dummy variables. Nevertheless, the impacts of enterprise systems on the firms' innovational performance may to some extent still be biased upward as a few firms might have their enterprise systems reported in 2004 not yet installed by the time they generated their innovations. As the 2004 survey began in April, this source of endogeneity bias should be rather small but despite that, the results should be interpreted carefully. In the following section, the potential size of this bias will be checked via auxiliary regressions. The estimation procedure using enterprise systems reported in 2004 can only capture short-term innovational effects of a time space covering two years or less between the realized innovation and the enterprise system adoption. Therefore, the additional auxiliary regressions will also focus on revealing any long-term innovational impacts of enterprise systems.

\footnotetext{
${ }^{2}$ The interpretation of an impact due to minor software use in comparison to no or complete use is impossible as the questionnaire does not make any distinctions between the levels of usage.
} 
Suffering from panel mortality and a large proportion of item-nonresponse, matching the data for the two periods returns nearly 1,100 observations. After dropping the banking sector ${ }^{3}$, I had 989 observations left for my final dataset. Table $1^{4}$ shows the descriptive statistics for the variables used in this study. To employ a well-defined temporal sequence in line with the reported enterprise system usage, all other explanatory variables also refer to the year 2004. The innovation measures, on the other hand, are taken from the survey of 2007, capturing the innovations in the time of 2004 to 2006. As there is no data available to measure the firms' physical capital stock, I follow, e. g., [15] by using the gross investment figures as an empirical proxy for the capital stock in the knowledge production function. In addition, Table 1 also contains the descriptive statistics for the industry affiliations and the location in the east respectively west part of Germany for the firms in the final sample.

Insert Table 1 about here

From 2004 to 2006, around 64 percent of the firms reported process innovations and 60 percent reported realized product innovations. As a measure for innovation intensity, the average amount of process innovations a firm has introduced in the mentioned time space results in 3 , for product innovations it turns out to be $5^{5}$. As innovational performance is highly influenced by former innovational experience $[12,16]$, the dataset also includes two dummy variables covering whether a firm was process or product innovator in the time span of 2001 to 2003 . About 75 percent of the firms in the dataset are former process innovators, 64 percent reported former product innovations. For 2004, the average firm size amounts to 213 employees and the mean investment is $€ 2,195.400$. The mean share of workers mainly using a personal computer for their work, as a proxy for the ICT intensity of the firm which is suspected to positively affect a firms' innovational performance, e. $g$.

\footnotetext{
${ }^{3}$ As the enterprise software packages in the German banking sector seem to significantly differ from the ones used in other sectors, I decided to drop that sector completely in order to reduce measurement errors.

${ }^{4}$ All Tables are located in the appendix.

${ }^{5}$ To correct for especially high outliers and to reduce potential measurement errors, I use the $95^{\text {th }}$ percentile of the reported quantities for both types of innovations.
} 
[17], amounts to around 47 percent in the used sample. Human capital is measured via the share of highly skilled workers, including degrees from university and technical college, and the share of medium skilled workers, including finished apprenticeships, in-firm trainings or technical degrees. The mean share of highly skilled workers amounts to around 23 percent in the given sample, for medium skilled workers it results in about 56 percent. The certification of the International Organization of Standardization (ISO) indicates that a firm applies an international standardized strategy in building new products or using new processes. Being ISO certificated values the projects of the certificated firm and, in general, makes them comparable to projects worldwide. In the literature, ISO certification is argued to positively affect innovations to some extent, e. g. [3, 28], making it a viable choice as a control variable in the present study. Around 44 percent of the firms in the used dataset are ISO certificated. Nearly 27 percent of the firms are located in East Germany. Enterprise systems are widely spread in the used sample, only around one quarter of the firms reports no enterprise systems at all. Especially common is the use of ERP, around 64 percent of the observed firms rely on this system. SCM systems are adopted from around 43 percent of the firms and about one half of the firms use CRM systems. All three enterprise systems together are employed by around 28 percent of the firms. Examining the industry affiliation of the firms, the biggest share, of around 12 percent, conducts business in metal and machine construction, only a few belong to the automobile or chemical industry ( 5 respectively 6 percent).

Table 2 reports the descriptives for a group of additional organizational dummy control variables which I expect to positively influence the firms' innovational performance. As shown in [17], the firms' innovation activity is not only influenced by the usage of ICT but also positively affected by certain organizational factors which allow for more employee flexibility. To capture the potential influence of these factors on firms' innovational activity, I include five organizational practices as controls in the estimation procedure. These organizational variables report if a firm has established accounts for working hours, uses job rotation, quality circles or relies on units with own cost and 
result responsibility or self dependent working groups. The percentage of firms which apply these practices varies from nearly 70 percent using accounts for working hours to 19 percent using job rotation techniques.

------ Insert Table 2 about here ------

To firstly offer descriptive evidence for potential impacts of enterprise systems on innovational performance, Table 3 shows additional statistics of the firms using enterprise systems. In addition, there lies a specific focus on the group of firms using no enterprise systems at all or the full suite of the systems. Comparing the average innovational performance for each group with the entire sample means reported in Table 1, it is easy to see that once the firms use enterprise software, every innovation measure exceeds the sample mean slightly. Firms which use all three enterprise systems together show the highest mean values. In contrast, using no enterprise system at all results in values lower than the sample mean. This result may be viewed as a first clue pointing to the suspected positive impact of enterprise systems on innovational performance. However, it does not provide any descriptive evidence for highly different impacts of specific enterprise systems on one type of innovations as argued in section 2. CRM users do not show higher mean values concerning product innovations and the mean values of ERP or SCM using firms are only slightly higher than those of CRM users in the case of process innovations.

------ Insert Table 3 about here ------ 


\section{Empirical Results}

\subsection{Model Selection}

As the first step of the estimation procedure a model which will be used in the given estimation setup has to be chosen. In doing so, the model selection is based on the three usual criteria, the log likelihood ratio, the Akaike and the Bayesian information criterion. According to [15], a bivariate model should be used for process and product innovations but the hypothesis of independence of both error terms, given the used covariates, is not rejected in the current dataset. Therefore, two separate models will be used for inference. In the following estimations, I use two specifications, one parsimonious specification without the mentioned additional organizational control variables and another one capturing the impacts of these control variables as well. For the estimation of the selection equation (1) I choose a probit ${ }^{6}$ model. Table 4 reports the criteria for the possible model choices based on the parsimonious specification as including the additional organizational control variables only changes the magnitude of the criteria slightly. Examining Table 4, it is easy to see that the negative binomial hurdle model performs best in all three considered categories for process as well as product innovations. In addition, a likelihood ratio test evaluating the Poisson model (dispersion parameter alpha $=0$ ) against the negative binomial distributed alternative given the employed covariates rejects the hypothesis of Poisson distribution usage in favor of the negative binomial distribution for all considered model types significantly at the one percent level. However, the Vuong-Test [37] of the zero-inflated against the hurdle model favours the zero-inflated model for process as well as product innovations with a test statistic significant at the one percent level. As Monte Carlo experiments evaluating the test and the other selection criteria in a negative binomial model setup are still lacking at the moment, the model choice becomes somewhat arbitrary.

\footnotetext{
${ }^{6}$ A logit specification could also be used to estimate equation (1). However, as the results are virtually the same compared to the ones obtained from the probit approach they are not pictured in this study.
} 
However, as the zeros of the underlying count process are directly identifiable in the present dataset, I stick to the frequently used hurdle model in the current analysis ${ }^{7}$.

Insert Table 4 about here

\subsection{Short-Term Impacts of Enterprise Systems on Innovation Propensity}

Table 5 reports the average marginal effects for the first part of the hurdle model containing the probit estimations $^{8}$ of equation (1) and pictures the mentioned short-term relation of two years or less for both process and product innovations. Column (1) and (2) of Table 4 display both specifications, the parsimonious one and the one including the organizational control variables, for the propensity to generate process innovations. The last two columns picture the results for both specifications concerning product innovations. As this study focuses especially on the impacts of enterprise systems on innovational performance, I will discuss other factors influencing innovational activity only briefly.

The estimation for process innovations shows that ERP and SCM system adoption, as expected, significantly increase the probability to generate process innovations. CRM system usage, on the other hand, shows no impact at all. These results hold also if the specification with all additional control variables is applied, although the coefficients of ERP and SCM decrease in size and the coefficient of SCM decreases one level in significance. For instance, the estimate of 0.109 in Column (2) of Table 5 indicates that the probability to realize process innovations is related to an increase of nearly 11 percentage points if the firm adopts a SCM system. For the adoption of an ERP system, the increase amounts to around 8 percentage points. Considering the other coefficients

\footnotetext{
${ }^{7}$ The results from the zero-inflated negative binomial model are roughly the same compared to the ones obtained from the hurdle alternative and are available from the author upon request.

${ }^{8}$ Only the marginal effects are discussed in the following section. The coefficients of the probit estimations can be found in Table 7.
} 
in Column (2), being a previous process innovator and using quality circles stand out in showing the highest values and significance levels, indicating a high positive impact on the likelihood to generate process innovations. An acquired ISO certification also seems to affect the probability to acquire process innovations positively, although only in the parsimonious specification. The share of highly skilled workers, on the other hand, shows a significantly negative impact on the probability to realize process innovations. This puzzling negative impact seems to account for the case that in contrast to product innovations, process innovations might in general not be initiated by the highly skilled workforce but by low to medium skilled workers working directly in the production process ${ }^{9}$.

The short-term impacts of enterprise systems on the probability to acquire new product innovations differ completely compared to the impacts on process innovations. ERP and SCM systems, as expected, seem to have no effect on firms' product innovational performance. Although based on a low significance level, CRM systems usage on the other hand shows a positive impact on the probability to acquire product innovations. This impact stays robust even if one controls for additional organizational practices. Considering the other coefficients in both columns, only being a product innovator in the last period and the share of highly skilled workers show a positive and highly significant impact on the likelihood of generating product innovations. An ISO certification also seems to positively affect the probability for product innovations as its impact turns out to be significant in the parsimonious specification. However, controlling for the firms' organizational practices, this impact vanishes. In addition, the propensity to acquire new product innovations seems to be positively affected by increases in gross investment figures, although the coefficient is based on a low significance level in both specifications.

\section{------ Insert Table 5 about here}

\footnotetext{
${ }^{9}$ In the current dataset this relation seems to hold as the spearman correlation coefficient between product innovations and highly skilled workers amounts to 0.25 significant at the one percent level compared to a slightly negative but non-significant coefficient between process innovations and highly skilled workers.
} 


\subsection{Short-Term Impacts of Enterprise Systems on Innovation Intensity}

Table 6 reports the estimation results of equation (2) for both specifications and process as well as product innovations. As in Table 5, the first two Columns (1) and (2) picture the results for process innovations, the last two Columns capture the results for product innovations. Having in mind the impacts from enterprise systems on the propensity to innovate pictured in Table 5, one would suspect similar results for innovation intensity. This implies a positive impact on process innovation intensity due to ERP and SCM system usage and a positive influence of CRM systems on product innovation intensity. Starting out with process innovations, the results show that the adoption of an ERP system is strongly positive related to process innovation intensity in the short-run. This holds for the parsimonious specification as well as for the specification including additional organizational control variables, although the coefficient decreases in size and significance in the second specification. SCM systems, on the other hand, fail to significantly increase the number of process innovations a firm realizes. The usage of a CRM system also does not have an impact on the intensity of process innovations. In addition, being a former process innovator and an acquired ISO certification show a highly significant positive influence on the intensity of process innovation in 2004 to 2006, although both coefficients decrease in size in the second specification with additional organizational variables included.

Having the estimates of the first part of the negative binomial hurdle model in mind, the results of Table 6 confirm, as expected, that both process orientated enterprise systems, i. e. ERP and SCM, have no impact on the intensity of product innovations. Surprisingly though is the non-existence of an impact due to CRM system usage. All three enterprise system coefficients turn out to be insignificant in both specifications, as shown in Column (3) and (4) of Table 6, indicating no impact of enterprise systems on product innovation intensity at all. Moving on to the other coefficients, only firm size and the usage of self dependent workgroups show a positive and significant impact on the intensity of product innovations. 
In addition, the dispersion coefficient alpha stays highly significant throughout all four columns of Table 6. The magnitude of these particular coefficients indicates a high overdispersion in the data and therefore strengthens the choice of the negative binomial distribution against the alternative of an underlying Poisson distribution. The overdispersion turns out to be larger in the case of process innovations.

Insert Table 6 about here

\subsection{Long-Term Impacts and Robustness Checks}

To identify potential long-term impacts and ensure the validity of the results so far, I apply additional regression procedures ${ }^{10}$. Besides revealing long-term influences of enterprise systems on innovational activities, these checks also provide information concerning the size of the possible endogeneity bias mentioned in section 4 . In the first step, the estimation procedure is completely repeated using the enterprise software adoption reported in the 2002 survey instead of the one from the survey in 2004, cutting the number of observation in half as now three surveys are used for estimation. Concerning ERP, the results obtained from the selected negative binomial hurdle model are roughly the same, i. e. show a significant impact of ERP on process innovation intensity, although this impact is based on a weaker significance level compared to the former estimation. The impact of ERP on process innovation propensity, on the other hand, stays significant at 10 percent level in the parsimonious specification but exceeds this threshold slightly (12 percent) if additional organizational practices are account for. Nevertheless, the results indicate that the size of the mentioned bias might be negligible small in the case of ERP. These results also offer a clue of a positive long-term impact of ERP on the firms' process innovational performance as the time

\footnotetext{
${ }^{10}$ The results of these auxiliary regressions are located in the second part of the appendix.
} 
difference between the adoption of the ERP and the realized process innovation covers two to four years in this regression.

The second robustness-check procedure regresses the same explanatory variables as before on the percentage of sales spent by the firms for research and development (R\&D) in 2006, using ordinary least squares, as this variable is not obtained via a count process. In the regression is controlled for former process as well as former product innovators. The variable covering R\&D spending could not be used as an explanatory variable in the former estimations concerning the short-term influence of enterprise systems as its value is only available for the entire year of 2006, making it an unsuitable choice to explain innovations in the time space of 2004 to 2006 . In this robustness-check regression $R \& D$ spending is viewed as pre-stage for innovations, indicating ongoing innovational activity. Concerning the estimation results, SCM shows a highly significant positive impact on R\&D spending of at least two years after its adoption, providing a clue towards long-term effects of SCM adoption on the firms' innovational performance as increased R\&D spending will in general result in new innovations.

Based on these results it seems that the adoption of ERP as well as SCM systems positively impacts the innovational performance of firms not only in the short- but also in the long-run. This indicates that the impacts of ERP and SCM reported in the short-run analysis might even be underestimated as a part of the impacts is only realized after a few years have passed and accordingly not captured in the short-term analysis. In addition, the enterprise systems used in this study are nowadays quite old (5 to 7 years) and there is no information about updates available. Thus, it may be the case that up to date enterprise systems provide even more functions to improve the firms' innovational performance. 


\section{Conclusion}

Enterprise systems are nowadays widely spread among different industries around the world. Although it is argued that enterprise systems increase firm performance, e. g. [1, 11, 19], their impact on innovational performance is at the moment only suspected. Empirical evidence concerning a relationship between enterprise systems and innovational performance is still missing at present.

The current study aims at filling this gap by empirically exploring the impact of the three main enterprise systems ERP, SCM and CRM on the innovational performance of firms for process as well as product innovations. Using a two step approach the results indicate a positive impact of ERP and SCM systems on the propensity to generate process innovations. The adoption of an ERP system also positively affects the numbers of realized process innovations. These results are not only short-term based but remain also stable if a long-run perspective is taken into account. The usage of CRM systems, on the other hand, does not have an impact on process innovations but positively impacts the propensity to realize product innovations on a short-term basis.

The results reveal a new aspect of benefits through enterprise system usage as besides expected productivity and efficiency gains enterprise systems might also foster the firms' innovational performance. Especially the increased process innovational performance due to ERP and SCM adoption might, in the long run, even cut down costs for the firm in a larger amount overall compared to the investments in enterprise systems. Therefore, managers should not only focus on costs and potential performance benefits in general when deciding to buy or upgrade enterprise systems.

Expected to significantly drive innovational performance, a potential short-coming of the analysis is the absence of an R\&D measure as an explanatory variable. Without controlling for R\&D intensity, 
all coefficients tend to be biased upward. Although the survey in 2007 contained R\&D investment for 2006, I decided not to include it in the estimation procedure as this variable would introduce additional bias in the result as mentioned in section 5. However, the potential bias due to omission of R\&D should be rather small in the present study due to inclusion of the complete investments figures of the firms in 2004, as this variable also contains the complete R\&D spending in that year.

Also of concern, as the current study contains short- and long-term perspectives, is a timing issue. The current dataset offers no way to control for the age of the enterprise systems in use as the purchase time was not asked for. In line with that, there is also no information concerning the firms' legacy system usage and potential implementation problems. Future availability of new data may provide evidence even for these cases.

Although there is no suspicion, no case study evidence and neither a theoretical argument that a complementarity relationship among the enterprise systems, as shown for their impact on labor productivity in [11], could foster the innovational impact of enterprise systems, an effect based on potential complementarity cannot be ruled out completely. However, as the current analysis forms a starting point concerning the relationship between innovational performance and enterprise systems, revealing any complementarity aspects was no aim of this study and is accordingly passed on to future research. 


\section{References}

1. Aral, S., Brynjolfsson, E. and Wu, D. J. Which came first, IT or productivity? The virtuous cycle of investment and use in enterprise systems. In ICIS 2006 Proceedings, Paper 110, 2006.

2. Bach D. and Sallet J. The challenges of classification: emerging VoIP regulation in Europe and the United States. IE Working Paper 05-19, 2005.

3. Benner, M. J. and Tushman, M. Process Management and Technological Innovation: A Longitudinal Study of the Photography and Paint Industries. Administrative Science Quarterly 47 (2002), 676-706.

4. Cachon, G. and Fisher M. Supply chain inventory management and the value of shared information. Management Science 46, 8 (2000), 1032-1048.

5. Chen, I. J. Planning for ERP systems: analysis and future trends. Business Process Management 7, 5 (2001), 374-386.

6. Criscuolo, C., Haskel, J., and Slaughter, M. Why are some firms more innovative? Knowledge inputs, knowledge stocks and the role of global engagement. NBER working paper, No. 11479, 2005.

7. Cohen, M. A., Agrawal, N. and Agrawal, V. Winning in the Aftermarket. Harvard Business Review 84, 5 (2006), 129-138. 
8. Cotteleer, M. J. and Bendoly, E. Order lead-time improvement following enterprise-IT implementation: An empirical study, Management Information Systems Quarterly 30, 3 (2006), 643-660.

9. Davenport, T. H. Putting the Enterprise into the Enterprise system, Harvard Business Review 76, 4 (1998), 121-132.

10. Dehning, B., Richardson, V. J., and Zmud, R. W. The Financial Performance Effects of ITBased Supply Chain Management Systems in Manufacturing Firms, Journal of Operations Management 25, 1 (2007), 806-824.

11. Engelstätter, B. Enterprise Systems and Labor Productivity: Disentangling Combination Effects. ZEW Discussion Paper 09-040, 2009.

12. Flaig, G., and Stadler, M. Success breeds success. The Dynamics of the Innovation Process. Empirical Economics 19 (1994), 55-68.

13. Fritsch, M. Measuring the quality of regional innovation systems - A knowledge production function approach. International Regional Science Review 25, 1 (2002), 86-101.

14. Griliches, Z. Issues in assessing the contribution of R\&D to productivity growth. Bell Journal of Economics 10 (1979), 92-116.

15. Hall, B. H., Lotti, F., and Mairesse, J. Innovation and productivity in SMEs: empirical evidence for Italy. Small Business Economics 33 (2009), 13-33. 
16. Hempell, T. Does Experience Matter? Innovations and the Productivity of ICT in German Services. Economics of Innovation and New Technology 14, 4 (2005), 277-303.

17. Hempell, T., and Zwick, T. New Technology, Work Organisation, and Innovation. Economics of Innovation and New Technology 17, 4 (2008), 331-354.

18. Hendricks, K. B., Singhal, V. R., and Stratman, J. K. The Impact of Enterprise Systems on Corporate Performance: A Study of ERP, SCM and CRM System Implementations, Journal of Operations Management 25, 1 (2007), 65-82.

19. Hitt, L. M., Wou, D. J., and Zhou, X. Investment in Enterprise Resource Planning: Business Impact and Productivity Measures. Journal of Management Information Systems, 19, 1 (2002), 71-98.

20. Joshi, A. W., and Sharma, S.. Customer knowledge development: antecedents and impact on new product performance. Journal of Marketing 68 (2004), 47-59.

21. Katz, H. How to embrace CRM and make it succeed in an organization. Costa Mesa: SYSPRO White Paper, 2002.

22. Leeuwen, G. van, and Wiel, H. P. van der ICT, innovaties en productiviteit: Een analyse met Nederlandse bedrifsgegevens, CPB memorandum, no 61, 2003.

23. Mabert, V.A., Soni, A.K., and Venkataramanan, M.A. Enterprise resource planning survey of US manufacturing firms, Production \& Inventory Management Journal 41, 20 (2000), 52-58.

24. McAfee, A. The impact of enterprise resource planning systems on company Performance, At 
Wharton Electronic Supply Chain Conference, 1999.

25. McAfee, A. The Impact of Enterprise Information Technology Adoption on Operational Performance: An Empirical Investigation, Productions and Operations Management 11, 1 (2002), 33-53.

26. McAfee, A., and Upton, D. Vandelay Industries. Harvard Business School Case \# 9-697-037, Boston: Harvard Business School Publishing, 1996.

27. Miranda, A., and Rabe-Hesketh, S. Maximum likelihood estimation of endogenous switching and sample selection model for binary, count, and ordinal variables. The Stata Journal 6, 3 (2006), 285-308

28. Rehfeld, K. M., Rennings, K., and Ziegler, A. Integrated Product Policy and Environmental Product Innovations: An Empirical Analysis. Ecological Economics 61, 1 (2007), 91-100.

29. Roper, S., Du, J., and Love, J. H. Knowledge sourcing and innovation. Aston Business School Research Paper 0605, 2006.

30. Roper, S., Du, J., and Love, J. H. Modelling the innovation value chain. Research Policy 37 (2008), 961-977.

31. SAP. Annual Report. Mannheim: SAP; 2008.

Available at SAP: http://www.sap.com/germany/company/investor/reports/index.epx 
32. Scott, J.E., and Vessey, I. Implementing enterprise resource planning systems: The role of learning from failure. Information Systems Frontiers 2, 2 (2000), 213-232.

33. Shang, S., and Seddon, P.B. Assessing and managing the benefits of enterprise systems: the business manager's perspective. Information Systems Journal 12 (2002), 271-299.

34. Suresh, H. What is customer relationship management (CRM)? Supply Chain Planet, April 2004.

35. Terza, J. V. Estimating count data with endogenous switching: Sample selection and endogenous treatment effects. Journal of Econometrics 84 (1998), 129-154.

36. Tsai, W. Knowledge transfer in intraorganizational networks: Effects of network position and absorptive capacity on business unit innovation and performance. Academy of Management Journal 44 (2001), 996-1004.

37. Vuong, Q. H. Likelihood ration tests for model selection and non-nested hypothesis. Econometrica 57, 2 (1989), 307-333.

38. Winkelmann, R. Count Data Models with selectivity. Econometric Review 17, 4 (1998), 339359. 


\section{Appendix I - Main Analysis}

Table 1: Summary statistics

Variable

process innovations acquired in 2004 to 2006

amount of process innovations

product innovations acquired in 2004 to 2006

amount of product innovations

process innovations in 2001 to 2003

product innovations in 2001 to 2003

capital $^{1}$

labor $^{2}$

$\ln$ (capital)

$\ln$ (labor)

share of computer workers

share of highly skilled employees

share of medium skilled employees

International Organization of Standardization (ISO) certificated

East German heritage

no enterprise system

ERP

SCM

CRM

all three enterprise systems
Manufacturing Sectors

consumer goods

chemical industry

other raw materials

metal and machine construction

electrical engineering

precision instruments

automobile

Service Sectors

whole sale trade

retail trade

transport and postal services

electronic data transfer

technical services

other business-related services

Number of observations
Mean

0.635

3.103

0.600

5.005

0.755

0.654

2195.4

213.0

5.443

3.954

0.469

0.226

0.557

0.444

0.267

0.231

0.635

0.434

0.524

0.275

Std. Dev. $\quad$ DV $^{3}$

yes

4.057

yes

9.639

yes

yes

7525.5

636.4

2.148

2.148

0.329

0.259

0.262

yes

yes

yes

yes

yes

yes

yes

0.089 yes

0.047 yes

0.082 yes

0.123 yes

0.084 yes

0.075 yes

0.058

yes

$\begin{array}{ll}0.047 & \text { yes } \\ 0.069 & \text { yes } \\ 0.069 & \text { yes } \\ 0.089 & \text { yes } \\ 0.096 & \text { yes } \\ 0.074 & \text { yes }\end{array}$

989

Source: ZEW ICT survey 2004, 2007 and own calculations.

Notes: ${ }^{1}$ Capital is proxied by gross investment in $€ 1,000 .{ }^{2}$ Labor is measured in total number of employees. ${ }^{3}$ Dummy variable 
Table 2: Additional control variables - summary statistics

\begin{tabular}{l|cc} 
Variable & Mean & $\mathbf{D V}^{1}$ \\
\hline accounts for working hours & 0.704 & yes \\
job rotation & 0.191 & yes \\
quality circles & 0.425 & yes \\
units with own cost and result responsibility & 0.386 & yes \\
self dependent workgroups & 0.623 & yes \\
\hline
\end{tabular}

Source: ZEW ICT survey 2004, 2007 and own calculations. ${ }^{1}$ Dummy variable

Table 3: Descriptive analysis

\begin{tabular}{l|ccccc} 
& No system & All systems & ERP & SCM & CRM \\
\hline recent process innovator & 0.478 & 0.790 & 0.726 & 0.767 & 0.726 \\
number of process innovations mean & 1.783 & 4.039 & 3.764 & 3.935 & 3.590 \\
& $(2.774)$ & $(4.252)$ & $(4.402)$ & $(4.424)$ & $(4.274)$ \\
recent product innovator & 0.408 & 0.728 & 0.667 & 0.700 & 0.681 \\
number of product innovations mean & 2.142 & 7.167 & 6.002 & 6.859 & 6.197 \\
& $(5.045)$ & $(10.82)$ & $(10.15)$ & $(10.87)$ & $(10.45)$ \\
\hline
\end{tabular}

Notes: Standard errors in parentheses.

Source: ZEW ICT survey 2004, 2007 and own calculations.

Table 4: Model selection

Process innovations

Product innovations

\begin{tabular}{|c|c|c|c|c|c|c|}
\hline Model & $\begin{array}{c}\text { Log } \\
\text { Likelihoo }\end{array}$ & $\mathrm{AIC}$ & $\mathrm{BIC}$ & $\begin{array}{c}\text { Log } \\
\text { Likelihood }\end{array}$ & AIC & $\mathrm{BIC}$ \\
\hline Poisson Hurdle & -2098.433 & 4292.867 & 4511.163 & -3425.688 & 6947.377 & 7162.924 \\
\hline Zero-inflated Poisson & -2098.093 & 4292.186 & 4522.165 & -3456.352 & 7008.704 & 7238.467 \\
\hline Neg. binomial Hurdle & -1873.352 & 3844.905 & 4067.505 & -1985.743 & 4069.487 & 4289.228 \\
\hline Zero-inflated neg. bin. & -1873.539 & 3845.077 & 4079.847 & -2017.872 & 4133.744 & 4368.293 \\
\hline Llhd.-ratio Test & \multicolumn{3}{|c|}{$449.220 * * *$} & \multicolumn{3}{|c|}{$2864.020 * * *$} \\
\hline Vuong-Test & \multicolumn{3}{|c|}{$6.050 * * *$} & \multicolumn{3}{|c|}{$7.830 * * *$} \\
\hline
\end{tabular}

Notes: $* * * \mathrm{p}<0.01 ; * * \mathrm{p}<0.05 ; * \mathrm{p}<0.1$; selected model in italic.

Source: ZEW ICT survey 2004, 2007 and own calculations. 
Table 5: Innovation selection - probit part of hurdle model (only marginal effects reported)

dependent variable: generation of process innovations

\begin{tabular}{|c|c|c|c|c|}
\hline & (1) & (2) & (3) & (4) \\
\hline $\ln$ (labor) & $\begin{array}{c}0.013 \\
(0.019)\end{array}$ & $\begin{array}{c}0.001 \\
(0.020)\end{array}$ & $\begin{array}{l}-0.004 \\
(0.020)\end{array}$ & $\begin{array}{l}-0.012 \\
(0.021)\end{array}$ \\
\hline $\ln$ (capital) & $\begin{array}{l}-0.003 \\
(0.013)\end{array}$ & $\begin{array}{c}0.003 \\
(0.013)\end{array}$ & $\begin{array}{l}0.025^{*} \\
(0.015)\end{array}$ & $\begin{array}{l}0.025^{*} \\
(0.015)\end{array}$ \\
\hline share of computer & 0.112 & 0.112 & -0.003 & 0.004 \\
\hline workers & $(0.075)$ & $(0.076)$ & $(0.078)$ & $(0.079)$ \\
\hline share of high skilled & $-0.249 * *$ & $-0.237 * *$ & $0.307 * *$ & $0.317 * *$ \\
\hline workers & $(0.117)$ & $(0.119)$ & $(0.127)$ & $(0.128)$ \\
\hline $\begin{array}{l}\text { share of medium skilled } \\
\text { workers }\end{array}$ & $\begin{array}{l}-0.116 \\
(0.090)\end{array}$ & $\begin{array}{l}-0.118 \\
(0.090)\end{array}$ & $\begin{array}{c}0.016 \\
(0.097)\end{array}$ & $\begin{array}{c}0.015 \\
(0.097)\end{array}$ \\
\hline ISO certificated & $\begin{array}{c}0.108 * * * \\
(0.040)\end{array}$ & $\begin{array}{c}0.066 \\
(0.042)\end{array}$ & $\begin{array}{c}0.087 * * \\
(0.043)\end{array}$ & $\begin{array}{c}0.071 \\
(0.045)\end{array}$ \\
\hline $\begin{array}{l}\text { firm acquired process } \\
\text { innovations last period }\end{array}$ & $\begin{array}{c}0.147 * * * \\
(0.041)\end{array}$ & $\begin{array}{c}0.125^{* * * *} \\
(0.042)\end{array}$ & - & - \\
\hline $\begin{array}{l}\text { firm acquired product } \\
\text { innovations last period }\end{array}$ & - & - & $\begin{array}{c}0.330 * * * \\
(0.037)\end{array}$ & $\begin{array}{c}0.321 * * * \\
(0.038)\end{array}$ \\
\hline$\overline{\mathrm{ERP}}$ & $\begin{array}{l}0.080 * * \\
(0.041)\end{array}$ & $\begin{array}{l}0.072 * \\
(0.041)\end{array}$ & $\begin{array}{c}0.025 \\
(0.046)\end{array}$ & $\begin{array}{c}0.023 \\
(0.046)\end{array}$ \\
\hline $\mathrm{SCM}$ & $\begin{array}{c}0.109 * * * \\
(0.040)\end{array}$ & $\begin{array}{c}0.097 * * \\
(0.041)\end{array}$ & $\begin{array}{l}-0.039 \\
(0.046)\end{array}$ & $\begin{array}{l}-0.044 \\
(0.047)\end{array}$ \\
\hline CRM & $\begin{array}{c}0.049 \\
(0.039) \\
\end{array}$ & $\begin{array}{c}0.046 \\
(0.040) \\
\end{array}$ & $\begin{array}{l}0.074^{*} \\
(0.043)\end{array}$ & $\begin{array}{l}0.075^{*} \\
(0.043) \\
\end{array}$ \\
\hline $\begin{array}{l}\text { accounts for working } \\
\text { hours }\end{array}$ & - & $\begin{array}{c}0.037 \\
(0.040)\end{array}$ & - & $\begin{array}{c}0.043 \\
(0.043)\end{array}$ \\
\hline job rotation & - & $\begin{array}{c}0.001 \\
(0.048)\end{array}$ & - & $\begin{array}{c}0.007 \\
(0.050)\end{array}$ \\
\hline quality circles & - & $\begin{array}{c}0.147 * * * \\
(0.038)\end{array}$ & - & $\begin{array}{c}0.055 \\
(0.043)\end{array}$ \\
\hline $\begin{array}{l}\text { units with own cost and } \\
\text { result responsibility }\end{array}$ & - & $\begin{array}{c}0.045 \\
(0.040)\end{array}$ & - & $\begin{array}{c}0.016 \\
(0.044)\end{array}$ \\
\hline $\begin{array}{l}\text { self dependent work } \\
\text { groups }\end{array}$ & - & $\begin{array}{l}-0.027 \\
(0.037) \\
\end{array}$ & - & $\begin{array}{l}-0.044 \\
(0.040) \\
\end{array}$ \\
\hline control variables & $\begin{array}{l}\text { Industry } \\
\text { East }\end{array}$ & $\begin{array}{l}\text { Industry } \\
\text { East }\end{array}$ & $\begin{array}{l}\text { Industry } \\
\text { East }\end{array}$ & $\begin{array}{l}\text { Industry } \\
\text { East }\end{array}$ \\
\hline pseudo $\mathrm{R}^{2}$ & 0.097 & 0.111 & 0.201 & 0.208 \\
\hline number of observations & \multicolumn{2}{|c|}{890} & \multicolumn{2}{|c|}{886} \\
\hline
\end{tabular}

Notes: $* * * \mathrm{p}<0.01 ; * * \mathrm{p}<0.05 ; * \mathrm{p}<0.1$; robust standard errors in parentheses.

Source: ZEW ICT survey 2004, 2007 and own calculations. 
Table 6: Innovation intensity - negative binomial part of hurdle model

dependent variable: amount of generated process innovations

\begin{tabular}{|c|c|c|c|c|}
\hline & \multicolumn{2}{|c|}{ process innovations } & \multicolumn{2}{|c|}{ product innovations } \\
\hline & (1) & (2) & (3) & (4) \\
\hline $\ln$ (labor) & $\begin{array}{c}0.057 \\
(0.041)\end{array}$ & $\begin{array}{c}0.049 \\
(0.041)\end{array}$ & $\begin{array}{l}0.135^{*} \\
(0.071)\end{array}$ & $\begin{array}{l}0.156^{* *} \\
(0.073)\end{array}$ \\
\hline $\ln$ (capital) & $\begin{array}{l}-0.012 \\
(0.031)\end{array}$ & $\begin{array}{l}-0.016 \\
(0.032)\end{array}$ & $\begin{array}{c}0.003 \\
(0.054)\end{array}$ & $\begin{array}{l}-0.011 \\
(0.054)\end{array}$ \\
\hline share of computer & 0.117 & 0.120 & 0.238 & 0.260 \\
\hline workers & $(0.163)$ & $(0.167)$ & $(0.254)$ & $(0.252)$ \\
\hline share of high skilled & -0.264 & -0.299 & -0.402 & -0.449 \\
\hline workers & $(0.270)$ & $(0.275)$ & $(0.410)$ & $(0.401)$ \\
\hline share of medium skilled & -0.061 & -0.086 & 0.014 & 0.083 \\
\hline workers & $(0.208)$ & $(0.211)$ & $(0.346)$ & $(0.333)$ \\
\hline ISO certificated & $\begin{array}{c}0.226^{* *} \\
(0.091)\end{array}$ & $\begin{array}{c}0.189 * * \\
(0.092)\end{array}$ & $\begin{array}{l}-0.134 \\
(0.144)\end{array}$ & $\begin{array}{l}-0.089 \\
(0.140)\end{array}$ \\
\hline $\begin{array}{l}\text { firm acquired process } \\
\text { innovations last period }\end{array}$ & $\begin{array}{c}0.265^{* * *} \\
(0.096)\end{array}$ & $\begin{array}{c}0.238 * * \\
(0.010)\end{array}$ & - & - \\
\hline $\begin{array}{l}\text { firm acquired product } \\
\text { innovations last period }\end{array}$ & - & - & $\begin{array}{l}-0.051 \\
(0.176)\end{array}$ & $\begin{array}{l}-0.084 \\
(0.174)\end{array}$ \\
\hline ERP & $\begin{array}{l}0.268^{* *} \\
(0.105)\end{array}$ & $\begin{array}{l}0.265^{* *} \\
(0.105)\end{array}$ & $\begin{array}{c}0.018 \\
(0.153)\end{array}$ & $\begin{array}{l}-0.078 \\
(0.154)\end{array}$ \\
\hline SCM & $\begin{array}{c}0.052 \\
(0.089)\end{array}$ & $\begin{array}{c}0.048 \\
(0.092)\end{array}$ & $\begin{array}{c}0.135 \\
(0.141)\end{array}$ & $\begin{array}{c}0.094 \\
(0.137)\end{array}$ \\
\hline CRM & $\begin{array}{l}-0.065 \\
(0.095)\end{array}$ & $\begin{array}{l}-0.094 \\
(0.095) \\
\end{array}$ & $\begin{array}{c}0.106 \\
(0.134) \\
\end{array}$ & $\begin{array}{r}0.039 \\
(0.132) \\
\end{array}$ \\
\hline $\begin{array}{l}\text { accounts for working } \\
\text { hours }\end{array}$ & - & $\begin{array}{l}-0.050 \\
(0.094)\end{array}$ & - & $\begin{array}{l}-0.207 \\
(0.146)\end{array}$ \\
\hline job rotation & - & $\begin{array}{l}-0.010 \\
(0.097)\end{array}$ & - & $\begin{array}{c}0.027 \\
(0.134)\end{array}$ \\
\hline quality circles & - & $\begin{array}{c}0.077 \\
(0.085)\end{array}$ & - & $\begin{array}{l}-0.048 \\
(0.128)\end{array}$ \\
\hline $\begin{array}{l}\text { units with own cost and } \\
\text { result responsibility }\end{array}$ & - & $\begin{array}{c}0.113 \\
(0.087)\end{array}$ & - & $\begin{array}{c}0.194 \\
(0.129)\end{array}$ \\
\hline $\begin{array}{l}\text { self dependent work } \\
\text { groups }\end{array}$ & - & $\begin{array}{c}0.061 \\
(0.087) \\
\end{array}$ & - & $\begin{array}{c}0.350^{* * *} \\
(0.123) \\
\end{array}$ \\
\hline constant & $\begin{array}{c}1.094 * * * \\
(0.250)\end{array}$ & $\begin{array}{c}1.100 * * * \\
(0.257)\end{array}$ & $\begin{array}{l}1.096^{* *} \\
(0.483)\end{array}$ & $\begin{array}{l}0.911 * * \\
(0.466)\end{array}$ \\
\hline alpha & $\begin{array}{c}0.490 * * * \\
(0.056) \\
\end{array}$ & $\begin{array}{c}0.484 * * * \\
(0.056) \\
\end{array}$ & $\begin{array}{c}1.399 * * * \\
(0.160)\end{array}$ & $\begin{array}{c}1.338 * * * \\
(0.151) \\
\end{array}$ \\
\hline control variables & $\begin{array}{l}\text { Industry } \\
\text { East }\end{array}$ & $\begin{array}{c}\text { Industry } \\
\text { East }\end{array}$ & $\begin{array}{l}\text { Industry } \\
\text { East }\end{array}$ & $\begin{array}{c}\text { Industry } \\
\text { East }\end{array}$ \\
\hline number of observations & & & & \\
\hline
\end{tabular}

Notes: $* * * \mathrm{p}<0.01 ; * * \mathrm{p}<0.05 ; * \mathrm{p}<0.1$; robust standard errors in parentheses.

Source: ZEW ICT survey 2004, 2007 and own calculations. 
Table 7: probit part of hurdle model

dependent variable: generation of

\begin{tabular}{|c|c|c|c|c|}
\hline & \multicolumn{2}{|c|}{ process innovations } & \multicolumn{2}{|c|}{ product innovations } \\
\hline & (1) & (2) & (3) & (4) \\
\hline \multirow[t]{2}{*}{$\ln$ (labor) } & 0.035 & -0.003 & -0.011 & -0.030 \\
\hline & $(0.050)$ & $(0.052)$ & $(0.020)$ & $(0.054)$ \\
\hline \multirow[t]{2}{*}{$\ln$ (capital) } & -0.009 & -0.009 & $0.063^{*}$ & $0.064 *$ \\
\hline & $(0.035)$ & $(0.036)$ & $(0.037)$ & $(0.038)$ \\
\hline share of computer & 0.296 & 0.295 & -0.008 & -0.010 \\
\hline workers & $(0.197)$ & $(0.200)$ & $(0.198)$ & $(0.201)$ \\
\hline share of high skilled & $-0.658 * *$ & $-0.628 * *$ & $0.781 * *$ & $0.805^{* *}$ \\
\hline workers & $(0.308)$ & $(0.314)$ & $(0.323)$ & $(0.324)$ \\
\hline share of medium skilled & -0.307 & -0.312 & 0.041 & 0.039 \\
\hline workers & $(0.237)$ & $(0.238)$ & $(0.246)$ & $(0.246)$ \\
\hline \multirow[t]{2}{*}{ ISO certificated } & $0.288 * * *$ & 0.176 & $0.222 * *$ & 0.180 \\
\hline & $(0.107)$ & $(0.111)$ & $(0.111)$ & $(0.116)$ \\
\hline firm acquired process & $0.380 * * *$ & $0.325 * * *$ & - & - \\
\hline innovations last period & $(0.104)$ & $(0.107)$ & & \\
\hline firm acquired product & - & - & $0.853 * * *$ & $0.829 * *$ \\
\hline innovations last period & & & $(0.102)$ & $(0.104)$ \\
\hline \multirow[t]{2}{*}{$\overline{\text { ERP }}$} & $0.210 * *$ & $0.191^{*}$ & 0.062 & 0.059 \\
\hline & $(0.107)$ & $(0.107)$ & $(0.116)$ & $(0.117)$ \\
\hline \multirow[t]{2}{*}{ SCM } & $0.292 * * *$ & $0.258 * *$ & -0.100 & -0.112 \\
\hline & $(0.109)$ & $(0.112)$ & $(0.116)$ & $(0.118)$ \\
\hline \multirow[t]{2}{*}{ CRM } & 0.129 & 0.122 & $0.189^{*}$ & $0.190 *$ \\
\hline & $(0.103)$ & $(0.105)$ & $(0.109)$ & $(0.109)$ \\
\hline accounts for working & - & 0.096 & - & 0.110 \\
\hline hours & & $(0.105)$ & & $(0.109)$ \\
\hline \multirow[t]{2}{*}{ job rotation } & - & 0.002 & - & 0.017 \\
\hline & & $(0.127)$ & & $(0.126)$ \\
\hline \multirow[t]{2}{*}{ quality circles } & - & $0.395 * * *$ & - & 0.140 \\
\hline & & $(0.106)$ & & $(0.109)$ \\
\hline units with own cost and & - & 0.120 & - & 0.041 \\
\hline result responsibility & & $(0.107)$ & & $(0.112)$ \\
\hline self dependent work & - & -0.071 & - & -0.113 \\
\hline groups & & $(0.099)$ & & $(0.103)$ \\
\hline \multirow[t]{2}{*}{ constant } & -0.450 & -0.407 & $-1.466 * * *$ & $-1.439 * * *$ \\
\hline & $(0.284)$ & $(0.293)$ & $(0.301)$ & $(0.310)$ \\
\hline \multirow[t]{2}{*}{ control variables } & Industry & Industry & Industry & Industry \\
\hline & East & East & East & East \\
\hline pseudo $\mathrm{R}^{2}$ & 0.097 & 0.111 & 0.201 & 0.208 \\
\hline number of observations & & & & \\
\hline
\end{tabular}

Notes: ${ }^{* *} \mathrm{p}<0.01 ; * * \mathrm{p}<0.05 ; * \mathrm{p}<0.1$; robust standard errors in parentheses.

Source: ZEW ICT survey 2004, 2007 and own calculations. 


\section{Appendix II - Auxiliary Regressions}

Table 8: Robustness-check 1 - model selection

Process innovations Product innovations

\begin{tabular}{|c|c|c|c|c|c|c|}
\hline Model & $\begin{array}{c}\text { Log } \\
\text { Likelihoo }\end{array}$ & $\mathrm{AIC}$ & $\mathrm{BIC}$ & $\begin{array}{c}\text { Log } \\
\text { Likelihood }\end{array}$ & AIC & $\mathrm{BIC}$ \\
\hline Poisson Hurdle & -1032.793 & 2161.586 & 2348.154 & -1808.060 & 3712.118 & 3896.158 \\
\hline Zero-inflated Poisson & -1032.900 & 2161.801 & 2359.786 & -1807.956 & 3711.912 & 3909.262 \\
\hline Neg. binomial Hurdle & -944.881 & 1987.762 & 2177.979 & 1044.980 & 2187.960 & 2375.557 \\
\hline Zero-inflated neg. bin. & -944.943 & 1987.885 & 2189.995 & -1048.952 & 2195.903 & 2397.365 \\
\hline Llhd.-ratio Test & \multicolumn{3}{|c|}{$175.900 * * *$} & \multicolumn{3}{|c|}{$1517.570 * * *$} \\
\hline Vuong-Test & \multicolumn{3}{|c|}{$4.800 * * *$} & \multicolumn{3}{|c|}{$5.930 * * *$} \\
\hline
\end{tabular}

Notes: $* * * \mathrm{p}<0.01 ; * * \mathrm{p}<0.05 ; * \mathrm{p}<0.1$; selected model in italic.

Source: ZEW ICT survey 2004, 2007 and own calculations. 
Table 9: Robustness-check 1 - probit part of hurdle model (marginal effects reported)

dependent variable: generation of

process innovations

product innovations

\begin{tabular}{|c|c|c|c|c|}
\hline & proce & ations & produ & ations \\
\hline & (1) & (2) & (3) & (4) \\
\hline $\ln$ (labor) & $\begin{array}{c}0.016 \\
(0.028)\end{array}$ & $\begin{array}{l}-0.003 \\
(0.029)\end{array}$ & $\begin{array}{l}-0.010 \\
(0.029)\end{array}$ & $\begin{array}{l}-0.005 \\
(0.030)\end{array}$ \\
\hline $\ln$ (capital) & $\begin{array}{l}-0.003 \\
(0.020)\end{array}$ & $\begin{array}{l}-0.006 \\
(0.020)\end{array}$ & $\begin{array}{l}0.039^{*} \\
(0.020)\end{array}$ & $\begin{array}{l}0.038^{*} \\
(0.020)\end{array}$ \\
\hline share of computer & 0.064 & 0.052 & 0.057 & 0.074 \\
\hline workers & $(0.100)$ & $(0.101)$ & $(0.105)$ & $(0.106)$ \\
\hline share of high skilled & $-0.279 *$ & $-0.283^{*}$ & $0.456 * * *$ & $0.451 * *$ \\
\hline workers & $(0.157)$ & $(0.160)$ & $(0.177)$ & $(0.179)$ \\
\hline $\begin{array}{l}\text { share of medium skilled } \\
\text { workers }\end{array}$ & $\begin{array}{l}-0 . \\
(0 .)\end{array}$ & $\begin{array}{l}-0.007 \\
(0.128)\end{array}$ & $\begin{array}{c}0.052 \\
(0.135)\end{array}$ & $\begin{array}{c}0.046 \\
(0.135)\end{array}$ \\
\hline ISO certificated & $\begin{array}{c}0.119 * * \\
(0.054)\end{array}$ & $\begin{array}{c}0.089 \\
(0.056)\end{array}$ & $\begin{array}{c}0.080 \\
(0.060)\end{array}$ & $\begin{array}{c}0.071 \\
(0.061)\end{array}$ \\
\hline $\begin{array}{l}\text { firm acquired process } \\
\text { innovations last period }\end{array}$ & $\begin{array}{r}0.144 * * \\
(0.059)\end{array}$ & $\begin{array}{c}0.122 * * \\
(0.060)\end{array}$ & - & - \\
\hline $\begin{array}{l}\text { firm acquired product } \\
\text { innovations last period }\end{array}$ & - & - & $\begin{array}{c}0.313 * * * \\
(0.054)\end{array}$ & $\begin{array}{c}0.310 * * * \\
(0.054)\end{array}$ \\
\hline$\overline{\text { ERP }}$ & $\begin{array}{l}0.096^{*} \\
(0.059)\end{array}$ & $\begin{array}{c}0.093 \\
(0.061)\end{array}$ & $\begin{array}{c}0.011 \\
(0.062)\end{array}$ & $\begin{array}{c}0.015 \\
(0.062)\end{array}$ \\
\hline SCM & $\begin{array}{c}0.001 \\
(0.064)\end{array}$ & $\begin{array}{l}-0.013 \\
(0.066)\end{array}$ & $\begin{array}{c}0.028 \\
(0.071)\end{array}$ & $\begin{array}{c}0.033 \\
(0.072)\end{array}$ \\
\hline CRM & $\begin{array}{c}0.054 \\
(0.061)\end{array}$ & $\begin{array}{c}0.042 \\
(0.062)\end{array}$ & $\begin{array}{c}0.023 \\
(0.064) \\
\end{array}$ & $\begin{array}{c}0.022 \\
(0.064)\end{array}$ \\
\hline $\begin{array}{l}\text { accounts for working } \\
\text { hours }\end{array}$ & - & $\begin{array}{l}-0.007 \\
(0.056)\end{array}$ & - & $\begin{array}{l}-0.038 \\
(0.060)\end{array}$ \\
\hline job rotation & - & $\begin{array}{c}0.036 \\
(0.064)\end{array}$ & - & $\begin{array}{l}-0.009 \\
(0.068)\end{array}$ \\
\hline quality circles & - & $\begin{array}{c}0.159^{* * *} \\
(0.052)\end{array}$ & - & $\begin{array}{c}0.038 \\
(0.059)\end{array}$ \\
\hline $\begin{array}{l}\text { units with own cost and } \\
\text { result responsibility }\end{array}$ & - & $\begin{array}{l}0.092^{*} \\
(0.055)\end{array}$ & - & $\begin{array}{l}-0.018 \\
(0.060)\end{array}$ \\
\hline $\begin{array}{l}\text { self dependent work } \\
\text { groups }\end{array}$ & - & $\begin{array}{l}-0.017 \\
(0.053) \\
\end{array}$ & - & $\begin{array}{l}-0.022 \\
(0.057) \\
\end{array}$ \\
\hline control variables & $\begin{array}{c}\text { Industry } \\
\text { East }\end{array}$ & $\begin{array}{l}\text { Industry } \\
\text { East }\end{array}$ & $\begin{array}{l}\text { Industry } \\
\text { East }\end{array}$ & $\begin{array}{c}\text { Industry } \\
\text { East }\end{array}$ \\
\hline pseudo $\mathrm{R}^{2}$ & 0.101 & 0.122 & 0.194 & 0.196 \\
\hline number of observations & & & & \\
\hline
\end{tabular}

Notes: $* * * \mathrm{p}<0.01 ; * * \mathrm{p}<0.05 ; * \mathrm{p}<0.1$; robust standard errors in parentheses.

Source: ZEW ICT survey 2004, 2007 and own calculations. 
Table 10: Robustness-check 1 - negative binomial part of hurdle model

dependent variable: amount of generated process innovations

\begin{tabular}{|c|c|c|c|c|}
\hline & \multicolumn{2}{|c|}{ process innovations } & \multicolumn{2}{|c|}{ product innovations } \\
\hline & (1) & (2) & (3) & (4) \\
\hline $\ln$ (labor) & $\begin{array}{c}0.085 \\
(0.057)\end{array}$ & $\begin{array}{c}0.077 \\
(0.059)\end{array}$ & $\begin{array}{l}0.205^{*} \\
(0.111)\end{array}$ & $\begin{array}{l}0.195^{*} \\
(0.111)\end{array}$ \\
\hline $\ln$ (capital) & $\begin{array}{l}-0.029 \\
(0.045)\end{array}$ & $\begin{array}{l}-0.024 \\
(0.046)\end{array}$ & $\begin{array}{l}-0.036 \\
(0.079)\end{array}$ & $\begin{array}{l}-0.021 \\
(0.080)\end{array}$ \\
\hline share of computer & 0.271 & $0.370^{*}$ & $0.649 * *$ & 0.432 \\
\hline workers & $(0.211)$ & $(0.212)$ & $(0.310)$ & $(0.307)$ \\
\hline share of high skilled & -0.416 & -0.514 & $-0.890^{*}$ & -0.796 \\
\hline workers & $(0.368)$ & $(0.363)$ & $(0.515)$ & $(0.516)$ \\
\hline share of medium skilled & -0.318 & -0.389 & -0.160 & 0.065 \\
\hline workers & $(0.312)$ & $(0.320)$ & $(0.441)$ & $(0.415)$ \\
\hline ISO certificated & $\begin{array}{l}0.305 * * \\
(0.132)\end{array}$ & $\begin{array}{l}0.291 * * \\
(0.132)\end{array}$ & $\begin{array}{l}-0.059 \\
(0.186)\end{array}$ & $\begin{array}{c}0.057 \\
(0.192)\end{array}$ \\
\hline $\begin{array}{l}\text { firm acquired process } \\
\text { innovations last period }\end{array}$ & $\begin{array}{l}0.242 * \\
(0.138)\end{array}$ & $\begin{array}{c}0.224 \\
(0.142)\end{array}$ & - & - \\
\hline $\begin{array}{l}\text { firm acquired product } \\
\text { innovations last period }\end{array}$ & - & - & $\begin{array}{l}-0.271 \\
(0.213)\end{array}$ & $\begin{array}{l}-0.231 \\
(0.211)\end{array}$ \\
\hline ERP & $\begin{array}{l}0.230^{*} \\
(0.143)\end{array}$ & $\begin{array}{l}0.245^{*} \\
(0.142)\end{array}$ & $\begin{array}{l}-0.095 \\
(0.201)\end{array}$ & $\begin{array}{l}-0.181 \\
(0.208)\end{array}$ \\
\hline SCM & $\begin{array}{c}0.172 \\
(0.130)\end{array}$ & $\begin{array}{c}0.154 \\
(0.128)\end{array}$ & $\begin{array}{l}-0.147 \\
(0.186)\end{array}$ & $\begin{array}{l}-0.131 \\
(0.186)\end{array}$ \\
\hline CRM & $\begin{array}{l}-0.050 \\
(0.121)\end{array}$ & $\begin{array}{l}-0.072 \\
(0.118) \\
\end{array}$ & $\begin{array}{c}0.294 \\
(0.187) \\
\end{array}$ & $\begin{array}{c}0.299 \\
(0.193) \\
\end{array}$ \\
\hline $\begin{array}{l}\text { accounts for working } \\
\text { hours }\end{array}$ & - & $\begin{array}{l}-0.180 \\
(0.126)\end{array}$ & - & $\begin{array}{l}-0.174 \\
(0.182)\end{array}$ \\
\hline job rotation & - & $\begin{array}{c}0.041 \\
(0.125)\end{array}$ & - & $\begin{array}{c}0.198 \\
(0.175)\end{array}$ \\
\hline quality circles & - & $\begin{array}{c}0.163 \\
(0.121)\end{array}$ & - & $\begin{array}{l}-0.238 \\
(0.207)\end{array}$ \\
\hline $\begin{array}{l}\text { units with own cost and } \\
\text { result responsibility }\end{array}$ & - & $\begin{array}{c}0.074 \\
(0.108)\end{array}$ & - & $\begin{array}{c}0.057 \\
(0.176)\end{array}$ \\
\hline $\begin{array}{l}\text { self dependent work } \\
\text { groups }\end{array}$ & - & $\begin{array}{l}-0.084 \\
(0.114) \\
\end{array}$ & - & $\begin{array}{c}0.415^{* *} \\
(0.176) \\
\end{array}$ \\
\hline constant & $\begin{array}{l}1.580 * * * \\
(0.378)\end{array}$ & $\begin{array}{c}1.679 * * * \\
(0.395)\end{array}$ & $\begin{array}{c}1.767 * * * \\
(0.642)\end{array}$ & $\begin{array}{l}1.547 * * \\
(0.595)\end{array}$ \\
\hline alpha & $\begin{array}{c}0.410 * * * \\
(0.076)\end{array}$ & $\begin{array}{c}0.404 * * * \\
(0.073) \\
\end{array}$ & $\begin{array}{c}1.299 * * * \\
(0.191)\end{array}$ & $\begin{array}{c}1.230 * * * \\
(0.187) \\
\end{array}$ \\
\hline control variables & $\begin{array}{l}\text { Industry } \\
\text { East }\end{array}$ & $\begin{array}{c}\text { Industry } \\
\text { East }\end{array}$ & $\begin{array}{l}\text { Industry } \\
\text { East }\end{array}$ & $\begin{array}{c}\text { Industry } \\
\text { East }\end{array}$ \\
\hline number of observations & & & & \\
\hline
\end{tabular}

Notes: $* * * \mathrm{p}<0.01 ; * * \mathrm{p}<0.05 ; * \mathrm{p}<0.1$; robust standard errors in parentheses.

Source: ZEW ICT survey 2004, 2007 and own calculations. 
Table 11: Robustness-check 1 - probit part of hurdle model

dependent variable: generation of

\begin{tabular}{|c|c|c|c|c|}
\hline & \multicolumn{2}{|c|}{ process innovations } & \multicolumn{2}{|c|}{ product innovations } \\
\hline & (1) & (2) & (3) & (4) \\
\hline $\ln$ (labor) & $\begin{array}{c}0.041 \\
(0.075)\end{array}$ & $\begin{array}{l}-0.007 \\
(0.077)\end{array}$ & $\begin{array}{l}-0.025 \\
(0.073)\end{array}$ & $\begin{array}{l}-0.013 \\
(0.077)\end{array}$ \\
\hline $\ln$ (capital) & $\begin{array}{l}-0.007 \\
(0.053)\end{array}$ & $\begin{array}{l}-0.016 \\
(0.053)\end{array}$ & $\begin{array}{l}0.099^{*} \\
(0.051)\end{array}$ & $\begin{array}{l}0.099^{*} \\
(0.052)\end{array}$ \\
\hline share of computer & 0.170 & 0.140 & 0.146 & -0.192 \\
\hline workers & $(0.265)$ & $(0.271)$ & $(0.269)$ & $(0.273)$ \\
\hline share of high skilled & $-0.743 *$ & $-0.758 *$ & $1.174 * * *$ & $1.161 * *$ \\
\hline workers & $(0.417)$ & $(0.428)$ & $(0.455)$ & $(0.460)$ \\
\hline share of medium skilled & 0.014 & -0.018 & 0.133 & 0.120 \\
\hline workers & $(0.336)$ & $(0.341)$ & $(0.346)$ & $(0.348)$ \\
\hline ISO certificated & $\begin{array}{c}0.320 * * \\
(0.148)\end{array}$ & $\begin{array}{c}0.239 \\
(0.152)\end{array}$ & $\begin{array}{c}0.207 \\
(0.154)\end{array}$ & $\begin{array}{c}0.184 \\
(0.160)\end{array}$ \\
\hline $\begin{array}{l}\text { firm acquired process } \\
\text { innovations last period }\end{array}$ & $\begin{array}{c}0.374 * * \\
(0.152)\end{array}$ & $\begin{array}{c}0.319 * * \\
(0.155)\end{array}$ & - & - \\
\hline $\begin{array}{l}\text { firm acquired product } \\
\text { innovations last period }\end{array}$ & - & - & $\begin{array}{c}0.810^{* * *} \\
(0.145)\end{array}$ & $\begin{array}{c}0.802 * * * \\
(0.146)\end{array}$ \\
\hline$\overline{\mathrm{ERP}}$ & $\begin{array}{l}0.252 * \\
(0.153)\end{array}$ & $\begin{array}{c}0.244 \\
(0.158)\end{array}$ & $\begin{array}{c}0.029 \\
(0.158)\end{array}$ & $\begin{array}{c}0.038 \\
(0.159)\end{array}$ \\
\hline $\mathrm{SCM}$ & $\begin{array}{c}0.003 \\
(0.172)\end{array}$ & $\begin{array}{l}-0.033 \\
(0.175)\end{array}$ & $\begin{array}{c}0.073 \\
(0.184)\end{array}$ & $\begin{array}{c}0.084 \\
(0.188)\end{array}$ \\
\hline CRM & $\begin{array}{c}0.146 \\
(0.167)\end{array}$ & $\begin{array}{c}0.113 \\
(0.168) \\
\end{array}$ & $\begin{array}{c}0.059 \\
(0.166)\end{array}$ & $\begin{array}{c}0.057 \\
(0.167)\end{array}$ \\
\hline $\begin{array}{l}\text { accounts for working } \\
\text { hours }\end{array}$ & - & $\begin{array}{l}-0.018 \\
(0.150)\end{array}$ & - & $\begin{array}{l}-0.098 \\
(0.155)\end{array}$ \\
\hline job rotation & - & $\begin{array}{c}0.098 \\
(0.176)\end{array}$ & - & $\begin{array}{l}-0.022 \\
(0.175)\end{array}$ \\
\hline quality circles & - & $\begin{array}{c}0.434 * * * \\
(0.146)\end{array}$ & - & $\begin{array}{c}0.098 \\
(0.152)\end{array}$ \\
\hline $\begin{array}{l}\text { units with own cost and } \\
\text { result responsibility }\end{array}$ & - & $\begin{array}{l}0.249^{*} \\
(0.152)\end{array}$ & - & $\begin{array}{l}-0.0466 \\
(0.155)\end{array}$ \\
\hline $\begin{array}{l}\text { self dependent work } \\
\text { groups }\end{array}$ & - & $\begin{array}{l}-0.046 \\
(0.143)\end{array}$ & - & $\begin{array}{l}-0.057 \\
(0.147)\end{array}$ \\
\hline constant & $\begin{array}{l}-0.750 \\
(0.460)\end{array}$ & $\begin{array}{l}-0.600 \\
(0.479)\end{array}$ & $\begin{array}{c}-1.977 * * * \\
(0.513)\end{array}$ & $\begin{array}{c}-1.956 * * * \\
(0.520)\end{array}$ \\
\hline control variables & $\begin{array}{l}\text { Industry } \\
\text { East }\end{array}$ & $\begin{array}{c}\text { Industry } \\
\text { East }\end{array}$ & $\begin{array}{c}\text { Industry } \\
\text { East }\end{array}$ & $\begin{array}{l}\text { Industry } \\
\text { East }\end{array}$ \\
\hline pseudo $\mathrm{R}^{2}$ & 0.102 & 0.122 & 0.194 & 0.196 \\
\hline
\end{tabular}

Notes: $* * * \mathrm{p}<0.01 ; * * \mathrm{p}<0.05 ; * \mathrm{p}<0.1$; robust standard errors in parentheses.

Source: ZEW ICT survey 2004, 2007 and own calculations. 
Table 12: Robustness-check 2 - R\&D spending and enterprise system usage

\section{dependent variable: $R \& D$ spending in share of total sales}

(1)

\begin{tabular}{|c|c|c|}
\hline $\ln$ (labor) & $\begin{array}{l}-0.001 \\
(0.006)\end{array}$ & $\begin{array}{c}0.001 \\
(0.006)\end{array}$ \\
\hline $\ln$ (capital) & $\begin{array}{c}0.005 \\
(0.004)\end{array}$ & $\begin{array}{c}0.005 \\
(0.004)\end{array}$ \\
\hline share of computer & 0.016 & 0.014 \\
\hline workers & $(0.025)$ & $(0.025)$ \\
\hline $\begin{array}{l}\text { share of high skilled } \\
\text { workers }\end{array}$ & $\begin{array}{c}0.113 * * * \\
(0.040)\end{array}$ & $\begin{array}{c}0.117 * * * \\
(0.040)\end{array}$ \\
\hline $\begin{array}{l}\text { share of medium skilled } \\
\text { workers }\end{array}$ & $\begin{array}{c}0.010 \\
(0.022)\end{array}$ & $\begin{array}{c}0.012 \\
(0.022)\end{array}$ \\
\hline ISO certificated & $\begin{array}{l}-0.014 \\
(0.015)\end{array}$ & $\begin{array}{c}-0.010 \\
(0.0146)\end{array}$ \\
\hline $\begin{array}{l}\text { firm acquired process } \\
\text { innovations last period } \\
\text { firm acquired product } \\
\text { innovations last period }\end{array}$ & $\begin{array}{l}-0.020 \\
(0.016) \\
0.030 * * \\
(0.013)\end{array}$ & $\begin{array}{l}-0.019 \\
(0.015) \\
0.031 * * \\
(0.013)\end{array}$ \\
\hline$\overline{E R P}$ & $\begin{array}{c}0.012 \\
(0.014)\end{array}$ & $\begin{array}{c}0.010 \\
(0.014)\end{array}$ \\
\hline SCM & $\begin{array}{c}0.031 * * \\
(0.015)\end{array}$ & $\begin{array}{c}0.030 * * \\
(0.015)\end{array}$ \\
\hline CRM & $\begin{array}{l}-0.013 \\
(0.015)\end{array}$ & $\begin{array}{c}0.013 \\
(0.015)\end{array}$ \\
\hline $\begin{array}{l}\text { accounts for working } \\
\text { hours }\end{array}$ & - & $\begin{array}{l}-0.009 \\
(0.013)\end{array}$ \\
\hline job rotation & - & $\begin{array}{l}-0.001 \\
(0.016)\end{array}$ \\
\hline quality circles & - & $\begin{array}{l}-0.006 \\
(0.014)\end{array}$ \\
\hline $\begin{array}{l}\text { units with own cost and } \\
\text { result responsibility }\end{array}$ & - & $\begin{array}{l}-0.021 \\
(0.014)\end{array}$ \\
\hline $\begin{array}{l}\text { self dependent work } \\
\text { groups }\end{array}$ & - & $\begin{array}{c}0.029 * * * \\
(0.011)\end{array}$ \\
\hline constant & $\begin{array}{l}-0.018 \\
(0.029)\end{array}$ & $\begin{array}{l}-0.031 \\
(0.029)\end{array}$ \\
\hline control variables & $\begin{array}{l}\text { Industry } \\
\text { East }\end{array}$ & $\begin{array}{l}\text { Industry } \\
\text { East }\end{array}$ \\
\hline $\mathrm{R}^{2}$ & 0.1975 & 0.2064 \\
\hline
\end{tabular}

number of observations

729
(2)$$
0.001
$$

0.005

$(0.004)$

0.014

$(0.025)$

$(0.040)$

0.012

$(0.022)$

$-0.010$

.0146)

(0.015)

0.031 **

(0.014)

0.030 **

(0.015)

$-0.009$

$(0.013)$

$-0.001$

$(0.014)$

$0.029 * * *$

(0.029)

East

0.2064

Notes: $* * * \mathrm{p}<0.01 ; * * \mathrm{p}<0.05 ; * \mathrm{p}<0.1$; robust standard errors in parentheses.

Source: ZEW ICT survey 2004, 2007 and own calculations. 